See discussions, stats, and author profiles for this publication at: https://www.researchgate.net/publication/331754368

\title{
Factors affecting Palestinian customers' use of online banking services
}

Article in International Journal of Bank Marketing · March 2019

DOI: 10.1108/IJBM-08-2018-0210

\section{CITATIONS}

11

3 authors:

Mohammed Salem

University College of Applied Sciences

22 PUBLICATIONS 84 CITATIONS

SEE PROFILE

(1)

Grace S Walsh

National University of Ireland, Maynooth

12 PUBLICATIONS 192 CITATIONS

SEE PROFILE

Some of the authors of this publication are also working on these related projects:
576

Samir Baidoun

Birzeit University

11 PUBLICATIONS 258 CITATIONS

SEE PROFILE

Project Published Paper View project 


\section{e emeraldinsight}

\section{International Journal of Bank Marketing}

Factors affecting Palestinian customers' use of online banking services

Mohammed Z. Salem, Samir Baidoun, Grace Walsh,

\section{Article information:}

To cite this document:

Mohammed Z. Salem, Samir Baidoun, Grace Walsh, (2019) "Factors affecting Palestinian customers' use of online banking services", International Journal of Bank Marketing, https://doi.org/10.1108/

IJBM-08-2018-0210

Permanent link to this document:

https://doi.org/10.1108/lJBM-08-2018-0210

Downloaded on: 15 March 2019, At: 03:33 (PT)

References: this document contains references to 172 other documents.

To copy this document: permissions@emeraldinsight.com

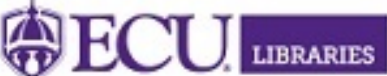

Access to this document was granted through an Emerald subscription provided by emeraldsrm: 161304 []

\section{For Authors}

If you would like to write for this, or any other Emerald publication, then please use our Emerald for Authors service information about how to choose which publication to write for and submission guidelines are available for all. Please visit www. emeraldinsight.com/authors for more information.

\section{About Emerald www.emeraldinsight.com}

Emerald is a global publisher linking research and practice to the benefit of society. The company manages a portfolio of more than 290 journals and over 2,350 books and book series volumes, as well as providing an extensive range of online products and additional customer resources and services.

Emerald is both COUNTER 4 and TRANSFER compliant. The organization is a partner of the Committee on Publication Ethics (COPE) and also works with Portico and the LOCKSS initiative for digital archive preservation.

*Related content and download information correct at time of download. 


\title{
Factors affecting Palestinian customers' use of online banking services
}

\author{
Mohammed Z. Salem \\ University College of Applied Sciences, Gaza, Palestine \\ Samir Baidoun \\ Department of Business Administration and Marketing, \\ Birzeit University, Birzeit, Palestine, and \\ Grace Walsh \\ College of Business, Public Policy and Law, \\ National University of Ireland, Galway, Ireland
}

\begin{abstract}
Purpose - The purpose of this paper is to examine factors that affect Palestinian customers' use of online banking services.

Design/methodology/approach - An empirical study was conducted using a questionnaire in order to test the hypotheses. The questionnaire was distributed to 500 respondents selected by the participating banks. A total of 369 complete questionnaires were returned. The study's independent variables include technology adoption propensity, customers' value for online personalization, customers' privacy concern, e-trust, technological leadership and loyalty. Palestinian customers' usage of online banking services is the dependent variable.

Findings - The results of the model tested clearly suggest that the use of online banking services is influenced, respectively, by the technological leadership, e-trust, e-loyalty, customers' value for online personalization, customers' concern for privacy and propensity of technology adoption. Finally, this paper suggests that policy makers should develop a prioritized hierarchy of actions in developing the effective use of bank's online services, based on the $t$ - and $p$-values of the latter mentioned factors.

Research limitations/implications - One limitation of the study is relying on self-reported cross-sectional data collection, rather than longitudinal surveying. Despite such limitation, the study provides the Palestinian banking sector with recommendations to promote online banking services based on the empirically identified factors affecting such service adoption.

Practical implications - Palestinian banks should promote the adoption of online banking services by supporting personalization of services, privacy and trust. Customers should always be informed that their bank is among the first banks to introduce the latest state-of-the-art online services. Technology innovative and diverse online services should be offered by banks to attract customers.

Originality/value - Although numerous research studies have studied the factors affecting customers in using electronic and online banking services, few studies have considered such usage in the developing countries, such as Arab countries in general and Palestine in particular. This is the first study to examine the factors affecting the adoption of online banking services in Palestine. This study provides empirical evidence to fill in the gap by providing a deeper understanding of the factors affecting the usage of online banking services in the country. The findings of this study can help decision makers in the Palestinian banks to develop practical plans that might accelerate and expand the adoption of online banking emphasizing personalized and trusted services offered with high level of security and privacy.

Keywords E-loyalty, E-trust, Customers' concern for privacy, Customers' value for online personalization, Technology adoption propensity, Technology and leadership, Use of online banking services,

Palestinian customers

Paper type Research paper

Mohammed Z. Salem would like to thank Avempace III, Erasmus Mundus and the University of Deusto for giving him a scholarship so that he could pursue his Post Doc in Marketing at the University of Deusto in Bilbao, Spain. This research is a result of his mobility. Also, the author would like to thank Prof. Dr Rifat Rustom and Mr Nabil Sarraf for their continuous support.
\end{abstract}

Received 10 August 2018 Revised 11 October 2018 11 December 2018 Accepted 7 January 2019 customers' use of online banking 


\section{Introduction}

Given the fast growth of the internet and market globalization, most companies are attempting to attract and retain customers in an extremely competitive e-market (Shatat, 2017). Current mature information systems have significantly facilitated the development of more efficient banking services (Arora and Sandhu, 2018; Mansumitrchai and Al-Malkawi, 2011). Incorporating e-services is becoming extremely significant to provide customers with an excellent and interactive service (Bultum, 2014). In addition to essential and valuable services, customers now present demands regarding new levels of both convenience and flexibility which are not supported in traditional means (Alsamydai et al., 2012). As a result, companies are changing their focus to e-services to support their complete business processes before and after transaction-related stages. This increases the importance of understanding the factors that influence customers in using online banking services. Studying such factors is essential to ensure successful performance in the marketplace (Gilaninia et al., 2011). In the banking sector, the well-established and mature information systems currently used are having an enormous influence on the development of more efficient banking services (Arora and Sandhu, 2018; Mansumitrchai and Al-Malkawi, 2011).

The internet provides a prompt delivery channel, through which customer banking services can be delivered more conveniently and economically (Chiu et al., 2017). E-banking has achieved a massive improvement compared to the traditional banking system, due to the following reasons: leading to a considerable reduction in transaction processing cost; improving payment efficiency, financial services and the banker-customer relationship (AlKailani, 2016). Similarly, Qureshi et al. (2008) and Tarhini et al. (2016) showed that the shift to e-banking services has major benefits, including perceived usefulness, perceived ease of use, security and privacy, all of which are enhanced by online banking. This has motivated banks to offer e-banking services to their customers domestically and globally.

Several terms have been used to represent customer access to online banking services including e-banking, internet banking, online banking, etc. As the internet is the backbone of such services, we can choose to provide a definition of internet banking as "the use of the internet as a remote delivery channel for banking services" (Gopalakrishnan et al., 2003). Internet banking is vital to both the banks and their customers. For banks, internet banking reduces operational cost including staff resources and physical facilities. Branch management and sales can also be boosted by adopting internet banking (Hernando and Nieto, 2007). For bank customers, internet banking offers a wide range of electronic bank transactions regardless of the time and place (AlKailani, 2016). Additional benefits that banks can potentially achieve through the adoption of online banking include - but not limited to - cost savings, increased service quality and increased profits (Tarhini et al., 2016). This is due to the fact that banks will be able to reach wider geographical locations and thus reduce their operating costs including handling fees, transaction costs, manpower and overhead expenses (Tarhini et al., 2016). However, despite all these potential benefits, many customers are still reluctant to use it (Chiu et al., 2017). Some of the main customers' concerns from the use of internet banking mainly reflect their perceptions of the degree of complexity of such services, their perceptions of the skills and infrastructures required (e.g. computers, internet, etc.), and their feel of uncertainty including their fear of the lack of security and privacy while using these services (Dwivedi et al., 2014).

There is a lack of research on the significant role of internet banking services and the factors affecting customers in using such services. More research is essential to enable banks to better formulate their marketing strategies and enhance their future service usage. Previous research has been focusing on the interpersonal interaction when it comes to 
customers and service providers (Fischer et al., 1997; Goodwin, 1996; Hartline and Ferrell, 1996), with few studies examining the interaction of customers with a technological interface (Bashir and Albarbarawi, 2011). It is also evident that there is no broadly agreed classification of the factors affecting customers' use of online banking services (Ayyash, 2017; Peter, 2015; Gikonyo, 2014; Unyathanakorn and Rompho, 2014; Dalhatu et al., 2014; Mouakket, 2009; Tarhini et al., 2016).

The still evolving banking sector in Palestine is managed by Palestinian Monetary Authority (PMA). Regarded as the central bank of Palestine, the PMA was formed in 1994 by a presidential decree as an independent institution and later by an act of the Palestine Legislative Council. The act outlined the full authority and autonomy of the PMA to ensure the stability and effectiveness of the Palestinian financial system (PMA, 2017). According to PMA (2017), there are 15 commercial banks in the country with 200 branches and delegate offices. Seven banks are local (two of which are Islamic banks) and eight are offshore banks (seven Jordanian and one Egyptian bank).

In contrary to the wide use of internet banking services in developed countries, customers' use of internet banking services in developing countries has been slow. Previous research studies have not systematically addressed the internet banking usage in developing countries and the reasons behind the low penetration of bank online services (Maitah and Hodrab, 2015; Khrewesh, 2011; Al-Ajam and Nor, 2015; Khodakarami and Chan, 2013; Sohrabi et al. 2013; Nasri and Charfeddine, 2012; Al-Gahtani, 2011; Abu Shanab et al., 2010; Tarhini et al., 2016). Certainly, no previous work has addressed this issue in the Palestinian context. Thus, this is the first study to exclusively focus on identifying the critical factors affecting Palestinian customers in using online banking services.

\section{Theoretical background and hypotheses development}

\section{Theories and models of technology use}

Several studies discussed the barriers against customers' use of the internet banking services, some of these main barriers include infrastructures, privacy and security (Chiu et al., 2017). Various researchers have emphasized other factors including past satisfaction with previous online services providers by setting the service quality determinants, namely "satisfiers" such as attentiveness, responsiveness, care and friendliness; however, the "dissatisfiers" are integrity, reliability, responsiveness, availability and functionality (Johnston, 1995). Other researchers have found that the main restriction from using internet banking services is related to the usage constraints including insufficient training in the use of the internet banking interface that is provided by the bank's employees, which may lead the customers to drop use of the system even if they were mature banking customers (Sikdar et al., 2015). Other factors are resistance to change, lack of awareness of the benefits, usefulness and convenience of the internet banking services, high technology anxiety, high need for personal interaction and the availability of alternative models of banking including ATMs and telephone banking (Al Khasawneh, 2015). Therefore, several theories and models have been developed to explain the relationship between user beliefs, attitudes and behavioral intentions to use the technology (Tarhini et al., 2016). Some of these theories include the innovation diffusion theory (IDT), theory of reasoned action (TRA), theory of planned behavior (TPB), the social cognitive theory (SCT), the motivational model (MM), the model of perceived credibility utilization model (PCUM) and technology acceptance models (TAM) (Zhang et al., 2018).

The IDT is based on the idea that individual customers' adoption rate of any new technology depends on six innovation characteristics, named relative advantage, compatibility, complexity, observability, trialability and perceived risk (Al-Jabri and Sohail, 2012). The IDT has been highly criticized as it merely defines the elements that may affect customers' adoption of the internet banking services, but does not explain how

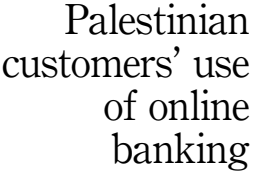


attitudes form and how they can be translated into individual customers' acceptance or rejection of the newly introduced technology (Mohammadi, 2015). The TRA has been developed by Fishbein and Ajzen (1975), and is considered one of the most widely used models of attitude and behavior. It consists of four main concepts that reflect the social influence that affect individual customers in their use of internet and other media sources, namely behavioral attitude, subjective norms, intention to use and actual use (Ajzen and Fishbein, 1980). This theory has been criticized widely as it only focuses on conscious behaviors that have been carefully thought of before actually doing, ignoring irrational decisions, habitual actions and any behaviors that are done unconsciously by customers (Al-Qeisi, 2009). An extension to the TRA is the TPB. According to TPB, customers' behavioral intentions to use the internet banking services are dependent on their attitudes, and subjective norms (Chiu et al., 2017). Two versions of the TPB had been studied; the pure traditional TPB, which only adds one additional construct on the TRA, mainly referred to as the perceived behavioral control, in order to account for situations where individuals lack complete control over their behavior. The decomposed TPB, on the other hand, added three attitudinal beliefs that may affect customers' adoption of internet banking, namely, relative advantage, complexity and comparability as part of the attitudinal belief factor that are mainly extracted from the IDT (Shih and Fang, 2004). The decomposed TPB is believed to have better explanatory power of individual customers' behavioral intentions to use internet banking services than the pure TPB and the TRA (Ajzen, 1991). However, the TPB theories have been criticized for introducing the perceived behavioral control factor as the solution to all non-controllable elements of behavior without specifying an actual measure for it (Taylor and Todd, 1995).

The SCT is a framework for understanding, predicting and changing individuals' behavior, mainly introducing human behavior as the result of the interaction between personal factors, behavior and the surrounding environment. The SCT is considered as an essential theory than can be used by researchers to understand and predict both individual and group behavior, and to identify methods in which their behavior can be modified or changed (Bandura, 1989).

The MM differentiated between two types of motivators that may affect individual customers' behavior, especially in the field of the adoption of new information technology services, intrinsic motivators and extrinsic motivators (Deci and Ryan, 1985). A third factor in the model is motivation, which is a state that occurs when individual customers lack a contingency between behavior and outcomes, or when there is an experience of incompetence and lack of control (Vallerand, 2000).

Within the context of internet banking services adoption, individual customers may actually adopt the internet banking services for its perceived enjoyment, self-efficacy, feelings of accomplishment, prestige, personal growth or mere pleasure as intrinsic motivators or for their perception of the usefulness of these services by saving them their personal time and efforts, or by banks' offering them price discounts as extrinsic motivators (Mohammadi, 2015).

The PCUM provided a framework to describe how the behavior occurs, and what factors encourage actual human behaviors in a voluntary environment (Al-Qeisi, 2009). The model was mainly used to understand and explain computer usage behavior in a voluntary environment.

The TAM is dependent on the TRA in regard of information systems (Zhang et al., 2018). It was developed by Davis (1989) to predict the main determinants of consumers' behavioral intentions toward the use of any new technology. It comprised of two main terms including perceived ease of use and perceived usefulness (Abdinoor and Mbamba, 2017). Perceived ease of use is defined as the extent to which an individual believes that using a particular system will be free of physical and mental effort (Al Khasawneh, 2015), while perceived 
usefulness refers to the degree to which a person believes that adopting a particular system would lead to the enhancement of his or her performance (Davis, 1989), mainly linking these two factors with customers' attitude toward the use of internet banking services.

The TAM has been criticized due to its poor explanatory power, and the inconsistent relationships among its two main elements (Al-Qeisi, 2009), in addition, it was believed that the model provides limited instructions to be followed to influence individual customers' usage of the internet banking services through design and implementation, as it does not provide any recommendations of improvement that may include the following; flexibility, integration, completeness of information and information currency (Venkatesh et al., 2003). Moreover, it was believed that the two main elements of the TAM cannot be relied upon solely to examine individual customers' technology acceptance tendencies (Al Khasawneh, 2015). Therefore, several constructs have been added to the TAM over time including perceived credibility, perceived trust, organizational factors, technology factors and individual differences. In addition, in an attempt to overcome the previous limitations, TAM2 was developed by adding the following moderating factors: social influence processes; including subjective norm, voluntariness and image; and cognitive instrumental processes mainly job relevance, output quality and result demonstrability (Al-Qeisi, 2009).

Analytical review of these seven models of technology use resulted in the unified theory of acceptance and use of technology (UTAUT) developed by Venkatesh et al. in 2003 after a six-month study conducted on four organizations. The model has been proven to be a valid research instrument and tool that is a predictor of adoption behavior and behavior intention with emphasis on performance expectancy and voluntariness as the most salient drivers of acceptance (Arora and Sandhu, 2018). The model was highly used in various studies of technology adoption and diffusion research, reaching up to 5,000 times being cited with reference to a range of technologies including the internet, websites and mobile technology among others (Williams et al., 2015).

The UTAUT consists of four main elements, performance expectancy, effort expectancy, social influence and facilitating conditions, explained in detail below. All of these elements are moderated by gender, age, experience and voluntariness of use (Venkatesh et al., 2003). Performance expectancy is mainly defined as the extent to which individual customers believe that using the internet banking services will improve their performance through saving them time, money and effort, and through offering them convenience of payment, fast response and service effectiveness. This factor is similar to perceived usefulness in the TAM, extrinsic motivation in the MM, relative advantage in the IDT and job fit in the PCUM. It is moderated by gender and age, as its effect is assumed to be higher for younger men. Another element is effort expectancy, referring to the perceived ease of use associated with using the internet banking system (Arora and Sandhu, 2018; Abdinoor and Mbamba, 2017; Mouakket, 2009). This factor is similar to perceived ease of use in the TAM, and complexity in the IDT. It is moderated by gender, age and experience, as its effect is hypothesized to be higher for older workers, and young women, especially at early stages of adoption (Tarhini et al., 2016). A third element defined is social influence, which refers to the social pressures from the individual customers' external environment that may affect their perceptions and behaviors of engaging in a certain decision such as the opinions of friends, relatives and superiors. This element is similar to subjective norms in the TRA, and TPB, and social factors in the PCUM. It is moderated by age, gender and experience, as its effect is assumed to be higher for younger women, especially in the early stages of use (Qin $e$ t al., 2011). A final element is facilitating conditions, which refers to the extent to which an individual believes that the right organizational and technical structure is available to support their adoption of the IB system. It is similar to perceived behavioral control in the

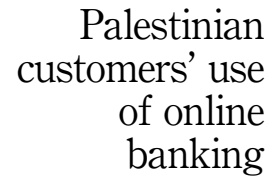


TPB, facilitating conditions in the PCUM and compatibility in the IDT. It is moderated by age, and experience, as its effect is hypothesized to be higher for older people, with increased experience (DeLone and Mclean, 2003).

However, based on past research, additional factors can be included in the model to improve its explanatory power. This would typically include perceived security and trust associated with the use of the internet banking services (perceived credibility). This factor has been widely addressed in past research, as a key reason for low adoption of internet banking services. Customers' perceived high uncertainty, intangibility, heterogeneity and vagueness resulting from using this online banking usually lead to their weak confidence in the internet banking channel (Mouakket, 2009). Having said that, additional effort was invested to review the marketing research literature representing the work of other researchers who studied other factors that affect the adoption of internet banking services. Such factors are related to propensity of technology adoption (Danyali, 2018; Chiu et al., 2017; Magotra et al., 2015; Ratchford and Barnhart, 2012), customers' value for personalization and privacy (Wang et al., 2017; Alhouti et al., 2016; Sreejesh et al., 2016; Chellappa and Sin, 2005), customers' trust (Chiu et al., 2017; Kaabachi et al., 2017; Estrella-Ramon et al., 2016), customers loyalty to internet services (Salegna, 2018; Amin, 2016; Falkenreck and Wagner, 2013; Kassim and Abdullah, 2008) and the technology leadership (Wittkop et al., 2018; Xu et al., 2014). The following section discusses these factors in details.

\section{Factors affecting customers in using online banking services}

Propensity of technology adoption. Technology adoption propensity of customers has clearly been identified as one of the most important factors to affect customers' usage of online banking services. It has been defined as the personal disposition of the customers, which is largely attributed to the value and belief system followed by the customers (Loukis and Kyriakou, 2015; Ratchford and Barnhart, 2012; Estrella-Ramon et al., 2016). Such propensity has a measurable influence in customers' decision in favor of self-service technologies (Magotra et al., 2015; Al-Smadi, 2012). Several factors are linked with technology adoption propensity (Potgieter et al., 2010; Tarhini et al., 2016; Chiu et al., 2017) including socioeconomics-related characteristics (Azouzi, 2009); technology attributes (Danyali, 2018; Ghobakhloo et al., 2012; Davis, 1989); and facilitating conditions (Schuster et al., 2016; Venkatesh et al., 2003). We propose the following technology propensity-related hypothesis:

H1. Customers' technology adoption propensity affects the use of online banking services.

Customers' value for online personalization. Customers use online personalization to mainly derive a better value from the online services offered. The real value provided by personalized services is based on the attributes on which personalization can be accomplished (Wang et al., 2017). There are different forms of personalized services on the web including personal portals such as my.yahoo.com, news portals and personalized anti-virus software (Awad and Krishnan, 2006). The level of personalization benefits that can be delivered is subject to the data that can be acquired. For example, automatic virus protection requires data, such as the customer's machine information, operating system and anti-virus software serial numbers. In the case of personal portals, information such as ZIP code is of a great importance when it comes to providing personalized commentaries on local weather and television programs (Alhouti et al., 2016). Online service personalization can be applied to content, presentation, access, delivery, advertisements and coupons (Påhlman, 2013). Personalization is centered on the following three attributes on which the value is delivered (Chellappa and Dutta, 2001). 
Personalization based on customer's attributes (non-purchase related). This type of personalization is based on customer attributes and is almost independent of any specific product purchase. This includes ZIP code, preferred language, shipping address, response to promotional activities and technology-specific attributes (e.g. browser type, IP address and connection device).

Personalization based on product-purchasing experience. Personalizing the productpurchasing experience to the customer's preferences enables a vendor to acquire a competitive advantage among vendors selling similar products. Firms such as Amazon and Barnes and Noble exploit collective knowledge (through collaborative filtering) of their entire customer base in order to keenly anticipate strong preferences of each individual customer to make far-reaching, personalized recommendations. Other firms employ personalized search, navigation or comparison screens which exclusively rely on user preferences.

Personalization of products themselves. Firms such as Dell and Gateway provide personalized page views that are tailored for individual customers to configure, order and pay for products online. Personalization after sale is also provided to strongly support the product purchased. Car manufacturers and furniture designers, widely known as physical product vendors, occasionally use the internet to create a favorable environment. They allow customers to provide inputs into their finally produced physical products. Products can be fully personalized in the case of digital goods and services (e.g. music albums, software bundles, stock quote recommendations).

Customers may exhibit various needs and expectations for each of the above-mentioned personalization types based on their own preferences. For example, a customer who travels frequently may value personalized services delivered to their mobile and hand-held devices. However, for a frequent shopper, product-purchase personalization will be more convenient. The aggregate value of personalization is a significantly important factor in the customer use of online services (Alhouti et al., 2016). Based on the above, we set the following hypothesis:

H2. Customers' value for online personalization affects the use of online banking services.

Customers' concern for privacy. The customer is usually concerned with privacy when using online services (Sreejesh et al., 2016). The degree of such privacy concern is individual specific. Individuals value privacy and have always been concerned about what and how much others know about them (Bandyopadhyay, 2012). However, research suggests that compensation may be a useful tool to reduce privacy concerns (e.g. Sheehan and Hoy, 2000; Milne and Gordon, 1993; Goodwin, 1991) as customers may be willing to exchange privacy to some degree for products, coupons, services or financial benefits (Xu et al., 2011; Chebat and Cohen, 1993; Barker, 1989). Similarly, it has been proposed that customers will trade their privacy for expected benefits of online personalization. Chellappa (2001) argues that a customer's perception of privacy in their transaction is a subjectively anticipated concept. It is defined as "the subjective probability with which he/she believes that the collection and subsequent access, use, and disclosure of his/her private and personal information are consistent with his/her expectations." Even if the expectations of privacy are typically set by known legal guidelines, customers themselves may have different assessments of privacy. Privacy has been looked at as a legal or human rights issue (Xu et al., 2011; Thomas and Maurer, 1997; Culnan, 1993). But, it has only recently been formally examined as a belief when it comes to a particular customer-marketer transaction as observed on the internet.

Chellappa (2001) provides scales for customer privacy perception. It was developed from Smith et al. (1996) and the FTC (1996) guidelines. These scales are designed to measure customers' subjective beliefs. Such beliefs are based on aspects of notice, choice, access, security and enforcement. However, generic assessment of privacy concerns may cause a problem due to the fact that privacy itself is deemed a "complex array of individual 
consumer attitudes" (FTC, 1996). Existing literature on public policy and marketing shines a light on dimensions of privacy other than those issued in the FTC-related guidelines. Analyses of related literature indicate that privacy concerns may be influenced by information sensitivity (Bandyopadhyay, 2012; Sheehan and Hoy, 2000). Therefore, to measure privacy concerns during the use of personalization services, it is worth making an assessment of the privacy perception in connection with information with varying sensitivity levels. Information can be categorized based on how personal it is using the FTC-related guidelines, as follows:

(1) Anonymous information: it refers to information gathered on page visits, without the use of any invasive technologies, sent with any web or internet request. Such information includes: the machine's IP address, domain type, browser version and type, operating system, browser language and local time.

(2) Personally non-identifying information: it refers to information that cannot identify or locate an individual. It includes age, date of birth, gender, occupation, education, income, ZIP code (without address details), interest and hobbies. The customer typically has to explicitly disclose such information through radio buttons, menus or check boxes on a web page. In addition to the explicit collection of information, tracking technologies such as cookies are used to gather further personal information. Collected information enables sketching an effective customer profile without identifying the customer individually.

(3) Personally identifying information: it refers to personal information that explicitly specifies the identity and/or location of an individual. This includes e-mail addresses, name, address, phone number, social security number, etc. Such information is usually gathered explicitly from the customer on service registration. Information elements can be combined to create an accurate user profile with their name and address known. For that reason, firms such as DoubleClick Inc. (an advertising network that can construct anonymous browsing profiles) were banned from acquiring physical addresses and mailing-list databases. The overall privacy concern of a customer is a function of the cumulative personal information rather than just individual information elements (Xu et al., 2011; Nam et al., 2006; Chellappa and Sin, 2001). Thus, we hypothesize the following:

H3. Customers' concern for privacy affects the use of online banking services.

E-trust. Trust tends to have a major effect upon most personal and business activities (Kaabachi et al., 2017). A general definition of trust is difficult and its interpretation is usually context based (Hsu and Wang, 2008; Thakur and Summey, 2007; McKnight and Chervany, 2001). Regarding e-business, trust has been defined as "the willingness of a party to be vulnerable to the actions of another party based on expectation that the other will perform a particular action important to the trustor, irrespective of the ability to monitor and control the other party" (Mayer et al., 1995, p. 712). E-trust has also been defined as "willingness to rely on an exchange partner in whom one has confidence" (Moorman et al., 1993, p. 82). The other party is characterized as reliable, honest, consistent and fair (Falkenreck and Wagner, 2017; Yousafzai et al., 2003; Shankar et al., 2002; Morgan and Hunt, 1994). An extensive review of the relevant literature has indicated that e-trust is a matter of perception and is built around key important components such as security and company published policies designed to safeguard confidential information of the customer (Estrella-Ramon et al., 2016; Mansour, 2016; Van Dyke et al., 2007; Pan and Zinkhan, 2006; Metzger, 2006; Faja and Trimi, 2006; Meinert et al., 2006; Pollach, 2005, 2006; Ashrafi and Kuilboer, 2005; Moores, 2005; Hong-Youl, 2004). 
Customers would probably be more willing to provide personal data online assuming that their level of trust justifies their disclosing of such data. Lotto (2001) suggested that enterprises should take five steps to help reducing customer concerns about privacy and thus building e-trust. Those steps are as follows:

(1) providing a clear notice concerning what sort of information is being collected, how it will be used and whether it will be disclosed to other parties;

(2) making customers choose freely whether, and by whom, their information can be reused;

(3) encouraging customers to review and amend their personal information files;

(4) controlling, monitoring and restricting access to customers' personal information; and

(5) letting customers know about the decisions being made on their behalf, the information which those decisions were based on and the implications of such decisions.

Given the relationship between e-trust and the use of online banking services that is indicated by previous research, we propose the following hypothesis:

H4. E-trust affects the use of online banking services.

Technological leadership. In line with technology, leadership plays a vital role in the success of internet banking services (Nanjundeswaraswamy and Swamy, 2014). To achieve online technological leadership, a bank is expected to provide support for a wide range of online banking services such as debit and credit cards, ATMs, cash management and payment solutions. Such services should be governed by organizational policies and procedures to ensure service provision excellence (Wittkop et al., 2018). Planning the introduction of new systems is crucial to achieve and maintain leadership. This includes identifying key players' responsibilities, coordination among departments, decisions on technical issues, security issues and management of logistics (Boateng et al., 2015). In addition, specialized training should also be provided on newly deployed systems with specific focus on customer services staff. Training sessions should involve new products features, marketing issues, security issues and technical management (Jaroslav, 2013).

We anticipate the following hypothesis:

H5. Technological leadership affects the use of online banking services.

E-loyalty. The concept of e-loyalty in online customer shopping experience (mediated by technology) is an extension of the traditional brand loyalty (Salegna, 2018; Falkenreck and Wagner, 2013; Mithas et al., 2006; Corstjens and Lal, 2000; Schultz, 2000; Reichheld and Schefter, 2000). E-loyalty is defined as the "intention to revisit a website" (Amin, 2016; Gommans et al., 2001; Corstjens and Lal, 2000). Loyal behavior may also involve the process of repurchasing (Srinivasan et al., 2002; Oliver, 1999; Dick and Basu, 1994). In this study, e-loyalty is considered as: perceived loyalty toward an online website, with intent to revisit the site or to make a purchase from it. Developing loyal customers plays an important role in achieving the firm's strategic goals as well as ensuring its survival (Nader and Rahim, 2015; Mittal and Kamakura, 2001; Gremler and Brown, 1999; Taylor and Baker, 1994). Increasing revenue and profitability is closely related to maintaining high levels of e-loyalty among customers (Donnelly et al., 2015; Aaker, 1997; Reichheld, 1993; Reichheld and Sasser, 1990).

In previous studies, loyalty was identified as a process of behavioral purchase (Jacoby, 1971) with psychological components (Oliver, 1999; Dick and Basu, 1994; Jacoby and Chesnut, 1978). Factors influencing loyalty include: ease of ordering, product information 
and selection, on-time delivery, customer confidence, adequate privacy policies, online resources and e-commerce quality (Grubor, 2009; Wolfinger and Gilly, 2000; Churchill, 1979).

More research studies on customer's attitude and purchase behavior have attempted to measure loyalty as a pattern of repeat purchases and statistical properties of loyalty (Flavian et al., 2006; Siekpe, 2005; Koufaris, 2002; Palmer, 2002; Yoon, 2002; Taylor and Baker, 1994). Relating satisfaction to e-loyalty, Devaraj et al. (2002, p. 185) claimed that "repeated satisfaction with purchases eventually leads to customer loyalty." Anderson and Srinivan (2003) tested whether the impact of customer satisfaction that brought on e-loyalty was moderated by business-level factors (i.e. trust, perceived value) and individual factors (i.e. inertia, convenience motivation and purchase size).

In online settings, as pointed out by Luarn and Lin, (2003, p. 156) "understanding how or why a sense of loyalty develops in customers remains one of the crucial management issues of our day." Delivering value-added services that are easily navigable and accessed enables online vendors to build sustaining relationships with customers (Chen and Yang, 2014; Kassim and Abdullah, 2008; de Ruyter et al., 2001). Gommans et al. (2001) offered a conceptual framework for e-loyalty (which remains untested), in which the authors suggest five elements making a contribution to e-loyalty: the value proposition (i.e. product customization, product quality and choice, pricing and brand recognition); brand building trust and security (i.e. evidence of third-party approval, privacy, company reputation and reliability); customer service (i.e. quick response to customer enquiries, ease of making contacts, easy payment options or fast delivery); and website and technology (i.e. ease of navigation, personalized features, design for targeted customers segments, language options, effective search functions). Four categories of e-loyalty have been identified based on product attachment, services offered and customer purchase patterns (Khajouei and Nayebzadeh, 2013; Wu, 2011; Griffin, 1995):

(1) No loyalty - a group of customers that never becomes loyal, chasing the best deal. To attract such customers, the company needs to employ an effective marketing strategy and always offer the best deal.

(2) Inertia loyalty - a group of customers are loyal just because they have to as there are no other competitors or options in the market. As a result, the customers are felt compelled to be loyal. Customers in this category tend to leave once there are other options in the market.

(3) Latent loyalty - a group of customers who remain loyal, in spite of not purchasing regularly, making them less profitable.

(4) Premium loyalty - such customers enjoy a friendly and healthy relationship with the vendor. With a high degree of retention, this customer group is not only keen to purchase the products and services being offered, but actively share their positive experiences with others. Companies should always be aiming to position their customer base in this loyalty category.

We identify the following hypothesis:

H6. E-loyalty affects the use of online banking services.

\section{Research framework}

Previous researchers (Xu et al., 2014; Ratchford and Barnhart, 2012; Srivastava et al., 2010; Mouakket, 2009; Kassim and Abdullah, 2008; Chellappa and Sin, 2005) have influenced the construction of the research model on which this study is based. The study's model includes 
normative and descriptive elements, as shown in Figure 1. Previous research work has contributed to the normative part of the model. However, we have fully developed the model's descriptive part, upon which the study is based.

\section{Methodology}

\section{Participants}

The sample subjects were bank customers in the two regions of Palestine, namely, the West Bank and Gaza Strip. Specifically, customers of the five Palestinian banks supporting online banking services participated in the study. Bank officials sent the link of the questionnaire by e-mail to their customers, who are subscribers of the online banking services. In total, 369 customers participated in the study. Their age distribution was as follows: 41.3 percent were aged 31-40 years, the largest percentage of the respondents. Age range 30 years or less represented 36.8 percent of respondents, while 16.8 percent of participants' age ranged from 41 to 50 years. Ages ranging from 51 to 60 constituted 4.3 percent and finally, 1 percent of the respondents were aged more than 61 years old. With regard to occupation, the largest percentage of respondents (46.3 percent) was private sector employees. Public sector employees represented 32.8 percent of the respondents, 9.8 percent were laborers and 1 percent were businessmen. The remaining 10.3 percent of respondents had other occupations. The qualification level of participants varied with the largest percentage of respondents (50 percent) holding a bachelor degree. Respondents with a diploma degree accounted for 23 percent, while 20.3 percent of respondents had a master degree. A total of 4.5 percent of respondents did not hold any higher education degrees, while the remaining (2.3 percent) of respondents were $\mathrm{PhD}$ graduates. Regarding respondents' income, 28.5 percent disclosed that their monthly salary was between $\$ 501$ and 1,000, while 26.5 percent received a $\$ 500$ or lower salary. A total of 25 percent of respondents disclosed a salary between $\$ 1,001$ and 1,500, while 11.3 percent receive a salary between $\$ 1,501$ and 2,000 . The remaining (8.8 percent) of respondents reported a salary more than $\$ 2,000$.

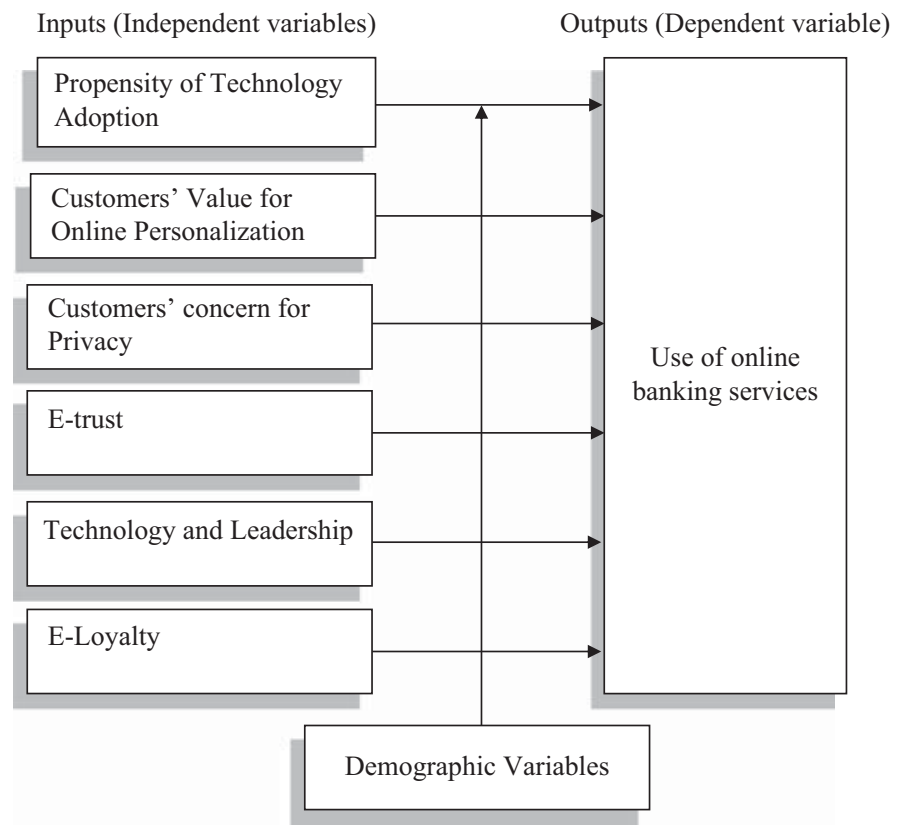

Palestinian customers' use of online banking 


\section{Procedure}

The study followed a descriptive approach that is appropriate to answer questions on the factors affecting Palestinian customers in using online banking services. The primary methodology of the study was survey research with data collected using a questionnaire. The original questionnaire was translated by a professional to the local Arabic language, and then reviewed by two Arabic native speakers. The Arabic version of the questionnaire was pilot tested for accuracy and content validity.

According to the PMA website, there are 5 banks out of 15 operating in Palestine use online banking services. The five banks officials informed the researchers of their agreement to cooperate with them. This approval by the banks was conditional on these banks sending the questionnaire link to their customers because the customers' data (including their names) is classified secret according to the applied system in the banking sector. A simple random sample of 384 was calculated at the confidence level of 95 percent by using the sample determination formula, which will give the researcher a margin error of only 5 percent (Saunders et al., 2012). The sample size in this research is more than the recommended number, which will increase the level of certainty. At the beginning of the questionnaire, after being given an explanation of the main concepts of our study, participants were asked whether they had used online banking services. If they answered yes, they carried on answering the survey. For each of the participating five banks, 100 questionnaires were sent to customers (the banks have almost the same customer base size). Out of 500 questionnaires distributed, 369 were returned complete and accurate.

PLS-SEM modeling was used to analyze the collected data with the SmartPLS 3.0 software tool. Analysis was based on the two-step approach recommended by Chin (1998) to evaluate structural equation models. In the first analysis stage, measurement items' (Ringle et al., 2015) validity and reliability were tested. Convergent and discriminant validity tests for the measurement (outer) model were performed. In addition, constructs reliability measures were considered including internal consistency and construct reliability. The square root of average variance extracted (AVE) and the correlation between latent constructs were compared to evaluate the discriminant validity. The structural (inner) model and hypotheses were tested in the second analysis stage. The research model's hypotheses relations were predicted using the coefficient of determination $\left(R^{2}\right)$. Bootstrapping based on 5,000 re-samples was performed to evaluate all hypothesized paths coefficients. Statistical analysis was also performed using the IBM SPSS software, version 21.0.

\section{Measures}

The survey instrument was a questionnaire with a five-point Likert scale $(1=$ strongly disagree, $2=$ disagree, $3=$ no opinion, $4=$ agree and $5=$ strongly agree). It was divided into eight parts, with personal information questions on the respondent's profile constituting the first part (five items). The second part was concerned with technology adoption propensity (six items) adapted from Ratchford and Barnhart (2012). The consumer's value for online personalization (three items) was considered in the third part of the questionnaire adapted from Chellappa and Sin (2005), Anderson and Gerbing (1988) and Bagozzi and Philips (1982). The fourth part inquired about the customer's concern for privacy (four items) adapted from Chellappa and Sin (2005), Chellappa (2001), Jarvenpaa et al. (2000) and Stewart and Segars (2002). The fifth part dealt with e-trust (seven items) adapted from Srivastava et al. (2010), Dinev and Hart (2006) and Polatoglu and Ekin (2001). Technological leadership (eight items) was considered in the sixth part adapted from $\mathrm{Xu}$ et al. (2014). The seventh part focused on loyalty (five items) adapted from Kassim and Abdullah (2008), while the last part of the questionnaire inquired about the use of online 
banking services (four items) adapted from Mouakket (2009). The questionnaire was reviewed and evaluated by marketing specialists. Statistics were calculated to guarantee the questionnaire's validity, reliability and to clarify any ambiguity in the questions. The researchers have modified, deleted and added the necessary parts of the questionnaire in response to the specialists' suggestions.
Palestinian customers' use of online banking

\section{Results}

\section{Measurement model assessment}

The reliability, discriminant and convergent validity of the measurement tool were assessed. As listed in Table I, Cronbach's $\alpha$ values, used to evaluate construct reliability, are higher (0.7) than the threshold specified by Nunnally and Bernstein (1994). This indicates the good reliability of the measurement tool.

The recommendation set by Henseler et al. (2009) specifying a 0.5 AVE value for each latent value was used to assess the convergent validity of the measurement tool. The AVE values of all constructs are higher than the 0.5 threshold as shown in Table I, confirming the measurement tool convergent validity.

The discriminant validity test was based on Fornell-Larker criterion (Fornell and Larcker, 1981). The criterion specifies that each latent construct AVE should be greater than the highest squared correlation between any other constructs. This is shown in our analysis as listed in Table II, confirming the discriminant validity of the measurement tool.

\section{Structural model assessment}

Results of the structural model assessment are shown in Table III. Path coefficients were evaluated for each hypothesized path to assess the structural model. In particular, the sign, magnitude and significance of path coefficients were considered. Bootstrapping based on 5,000 re-samples drawn with replacement was used to determine the significance of each estimated path. The structural model's explanatory power was assessed using the determination coefficient $R^{2}$, evaluating the model's ability to predict endogenous constructs.

The study findings indicate positive relation between the user of online banking services and the following: propensity of technology adoption $(t=2.108, p<0.000)$, customers' value for online personalization $(t=3.683, p<0.000)$, customers' concern for privacy $(t=2.620$, $p<0.000)$, e-trust $(t=6.384, p<0.000)$, technological leadership $(t=11.163, p<0.000)$ and e-loyalty $(t=3.860, p<0.000)$. This provides sufficient evidence to support $H 1-H 6$. It can be noted that the propensity of technology adoption has the least effect on the use of online banking services, as its factor loading was the lowest (listed in Table I). In addition, the three questions related to this construct with low loading values have been dropped from the measurement items. This can be due to the restrictions imposed on users based in Palestine to use payment gateways (e.g. PayPal) or credit cards for online payments. Thus, the number of customers making travel arrangements (Q2.1) and buying items with value above $\$ 100$ (Q2.2) are limited. In addition, some customers have security concerns in making online payments (Q2.3).

Finally, the Stone-Geisser $Q^{2}$ (predictive relevance) (Geisser, 1975; Stone, 1974) and the standardized root mean square residual (SRMR) were used to evaluate the model fit in PLS. $Q^{2}$ is a measure of how well the observed values are reproduced by the model and its estimated parameters. A $Q^{2}$ value greater than 0 indicates predictive relevance. The SRMR value of the composite model was 0.062, less than Hu and Bentler's (1999) recommended value of 0.08 , indicating a good model fit. The value of adjusted $R^{2}$ was 0.675 , implying that 67.5 percent of the variance in use of online banking services is accounted for by the independent variables. 


\begin{tabular}{|c|c|c|c|c|c|}
\hline Construct & Item & $\begin{array}{l}\text { Factor } \\
\text { loading } \\
\text { (FL) }\end{array}$ & $\begin{array}{l}\text { Composite } \\
\text { reliability } \\
\text { (CR) }\end{array}$ & $\begin{array}{l}\text { Cronbach's } \\
\alpha(\mathrm{CA})\end{array}$ & $\begin{array}{l}\text { Average } \\
\text { variance } \\
\text { extracted } \\
\text { (AVE) }\end{array}$ \\
\hline \multirow{4}{*}{$\begin{array}{l}\text { Technology } \\
\text { adoption } \\
\text { propensity }\end{array}$} & 2.1. Usually, I buy items costing over $\$ 100$ online & 0.856 & \multirow[t]{4}{*}{0.738} & \multirow[t]{4}{*}{0.729} & \multirow[t]{4}{*}{0.708} \\
\hline & $\begin{array}{l}2.2 \text {. I am signed up for any household utility, such as } \\
\text { electric or water, and mobile and pay the bills online }\end{array}$ & 0.705 & & & \\
\hline & 2.3. I own a "smart phone" with internet access & 0.731 & & & \\
\hline & $\begin{array}{l}\text { 2.4. I used an online bank that did not have a brick and } \\
\text { mortar location }\end{array}$ & 0.726 & & & \\
\hline \multirow{3}{*}{$\begin{array}{l}\text { Customers' } \\
\text { value for } \\
\text { online } \\
\text { personalization }\end{array}$} & 3.1. I value web pages that are personalized for the & 0.990 & \multirow[t]{3}{*}{0.989} & \multirow[t]{3}{*}{0.983} & \multirow[t]{3}{*}{0.968} \\
\hline & $\begin{array}{l}\text { 3.2. I appreciate personalized service based on } \\
\text { automatically collected information } \\
\text { (e.g. IP address, pages viewed) }\end{array}$ & 0.982 & & & \\
\hline & $\begin{array}{l}\text { 3.3. I am content using the web to purchase services } \\
\text { and products }\end{array}$ & 0.981 & & & \\
\hline \multirow{4}{*}{$\begin{array}{l}\text { Customers' } \\
\text { concern for } \\
\text { privacy }\end{array}$} & $\begin{array}{l}\text { 4.1. I am sensitive about giving out information } \\
\text { regarding my preferences }\end{array}$ & 0.934 & \multirow[t]{4}{*}{0.967} & \multirow[t]{4}{*}{0.954} & \multirow[t]{4}{*}{0.878} \\
\hline & $\begin{array}{l}\text { 4.2. I am concerned about anonymous information that } \\
\text { is collected about me online }\end{array}$ & 0.940 & & & \\
\hline & $\begin{array}{l}\text { 4.3. I worry about how my personally } \\
\text { un-identifiable information (information } \\
\text { given voluntarily but cannot be used to identify me) } \\
\text { will be used by the bank }\end{array}$ & 0.939 & & & \\
\hline & $\begin{array}{l}\text { 4.4. I care about how my personally identifiable } \\
\text { information (information given voluntarily that can be } \\
\text { used to identify me) will be used by the bank }\end{array}$ & 0.936 & & & \\
\hline \multirow[t]{7}{*}{ E-trust } & $\begin{array}{l}\text { 5.1. The bank's website demonstrates technical } \\
\text { expertise and skills }\end{array}$ & 0.702 & \multirow[t]{7}{*}{0.763} & \multirow[t]{7}{*}{0.731} & \multirow[t]{7}{*}{0.714} \\
\hline & 5.2. The bank's website is reliable & 0.713 & & & \\
\hline & $\begin{array}{l}\text { 5.3. The information exchanged over the bank's } \\
\text { website is between the bank and customer }\end{array}$ & 0.719 & & & \\
\hline & $\begin{array}{l}\text { 5.4. The information quality provided by the bank's } \\
\text { website is consistent }\end{array}$ & 0.750 & & & \\
\hline & $\begin{array}{l}\text { 5.5. The website of my bank appears to be well } \\
\text { qualified in banking sector }\end{array}$ & 0.720 & & & \\
\hline & 5.6. The bank's website is ethical & 0.726 & & & \\
\hline & 5.7. The bank's website has a strong sense of integrity & 0.703 & & & \\
\hline \multirow[t]{8}{*}{$\begin{array}{l}\text { Technology } \\
\text { and leadership }\end{array}$} & $\begin{array}{l}\text { 6.1. The bank keeps rolling out state-of-the-art } \\
\text { technologies }\end{array}$ & 0.708 & \multirow[t]{8}{*}{0.814} & \multirow[t]{8}{*}{0.782} & \multirow[t]{8}{*}{0.746} \\
\hline & $\begin{array}{l}\text { 6.2. The bank frequently introduces technological } \\
\text { innovations for its customers }\end{array}$ & 0.742 & & & \\
\hline & $\begin{array}{l}\text { 6.3. The bank is always among the first that introduce } \\
\text { the latest generation of technology }\end{array}$ & 0.733 & & & \\
\hline & $\begin{array}{l}\text { 6.4. The bank always deploys innovative technologies } \\
\text { to the market before others }\end{array}$ & 0.757 & & & \\
\hline & $\begin{array}{l}\text { 6.5. The bank keeps introducing new online } \\
\text { services to the customers }\end{array}$ & 0.760 & & & \\
\hline & $\begin{array}{l}\text { 6.6. The bank frequently innovates its online service } \\
\text { offerings for its customers }\end{array}$ & 0.749 & & & \\
\hline & 6.7. The bank offers a great variety of online services & 0.760 & & & \\
\hline & $\begin{array}{l}\text { 6.8. The bank always provides a diversified selection } \\
\text { of services for its customers }\end{array}$ & 0.825 & & & \\
\hline \multirow[t]{3}{*}{ E. loyalty } & $\begin{array}{l}\text { 7.1. The price is more than fair for the bank online } \\
\text { services I receive }\end{array}$ & 0.834 & \multirow[t]{3}{*}{0.899} & \multirow[t]{3}{*}{0.862} & \multirow[t]{3}{*}{0.642} \\
\hline & $\begin{array}{l}\text { 7.2. I take pleasure in being a customer of the bank } \\
\text { online services }\end{array}$ & 0.797 & & & \\
\hline & $\begin{array}{l}\text { 7.3. I will continue dealing with the bank online } \\
\text { services in the future }\end{array}$ & 0.775 & & & \\
\hline
\end{tabular}

Table I.

Reliability and loading values of the constructs 


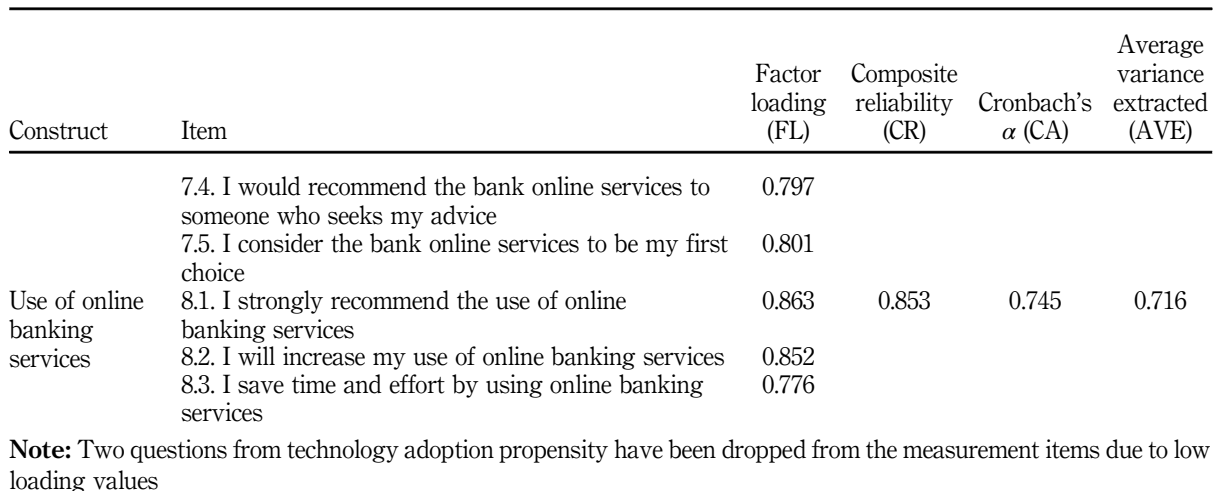

Palestinian customers' use of online banking loading values

Table I.

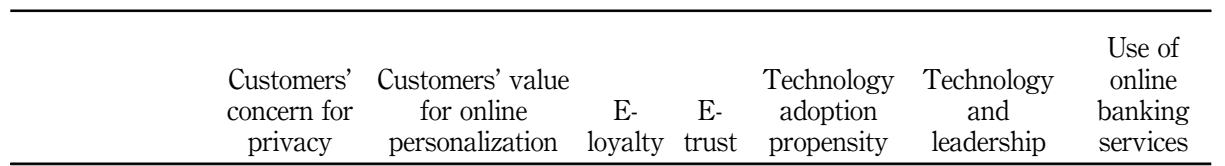

Customers'

concern for

privacy

0.937

Customers' value

for online

personalization

E-loyalty

E-trust

0.843

0.581

0.509

0.529

0.529

0.801

Technology

adoption

propensity

0.071

0.052

$0.534 \quad 0.549$

Technology and

leadership

0.500

0.426

$0.066 \quad 0.141$

0.590

Use of online

banking services

0.427

0.434

$0.527 \quad 0.949$

0.152

0.564

$\begin{array}{lll}0.528 & 0.662 & 0.169\end{array}$

0.766

0.802

Table II.

Discriminant validity of the constructs

\begin{tabular}{lccc}
\hline Independent variables & $t$-value & $p$-value & Result \\
\hline Propensity of technology adoption & 2.108 & 0.035 & Supported \\
Customers' value for online personalization & 3.683 & 0.000 & Supported \\
Customers' concern for privacy & 2.620 & 0.009 & Supported \\
E-trust & 6.384 & 0.000 & Supported \\
Technology and leadership & 11.163 & 0.000 & Supported \\
E-loyalty & 3.860 & 0.000 & Supported
\end{tabular}

Notes: $R^{2}=0.675$. Model fit (SRMR: saturated model $=0.062$; estimated model $=0.062$ )

Table III.

Summary of the structural model assessment results

Table IV indicates differences in the sample evaluations toward the use of online banking services based on age, employment category, education level, marital status and monthly salary. This is evident as the calculated $F$ is bigger than the tabulated $F$, and significance is lower than 5 percent. To identify where the significant differences occurs, the post hoc Scheffe test was employed. The Scheffe analysis revealed that the statistically significant 
differences were found between the age groups 30 years old and less, $31-40$, and $51-60$. This difference was in favor of the age group 30 years old and less. In addition, there are statistically significant differences between the age groups $31-40$ and 51-60. The results were in favor of the younger age group (31-40). Thus, the younger the customers are, the more likely they use the online banking services. This is expected as computer illiteracy levels are better among young people in addition to their better training in using modern information technology systems.

In terms of employment category, the Scheffe analysis revealed that the statistically significant differences were found between public sector employee and the others category. The results revealed that public sector employees use the online banking services more than respondents with the others occupation category.

Regarding the education level, the Scheffe analyses disclosed that statistically significant differences existed between respondents in the diploma degree and the bachelor degree groups. The results indicate that higher degree customers are more likely to use online banking services. This could be attributed to the fact that university graduates are more exposed to technology applications while studying compared to graduates of community colleges.

With regard to monthly income, the findings showed that there were statistically significant differences among the respondents groups $\$ 500$ or lower and $\$ 1,001-1,500$. The results indicate that the higher the income, the higher the tendency to use online banking services. This is easily attributed to the fact that customers of higher income have more banking activities to meet their needs.

\section{Discussion}

\section{Discussion of findings}

After careful and thorough statistical analysis of the data collected, it became evident that the use of banks' online services mainly depends on: technology adoption propensity, customers' value for online personalization, customers' concern for privacy, e-trust, technological leadership and e-loyalty. As shown in Table III, the $t$-values of factors affecting Palestinian customers to use online banking services reveal that the technological leadership factor has the highest $t$-value $(t=11.163, p<0.000)$, while e-trust factor has the second highest $t$-value $(t=6.384, p<0.000)$. The third factor was "e-loyalty" as its $t$-value was $3.860(p<0.000)$, while the respondents ranked "customers' value for online personalization" as the fourth factor with a $t$-value of $3.683(p<0.000)$. Finally, customers' concern for privacy, and propensity of technology adoption factors came fifth and sixth with $t$-values of $2.620(p<0.000)$ and $2.108(p<0.000)$, respectively. This indicates the priorities that decision/policy makers in the banking sector should take into account when developing strategies/policies to promote online banking services. The results suggest a prioritized hierarchy (based on the $t$ - and $p$-values of each factor item) of actions in developing the effective use of bank's online services as follows.

First, the technological leadership factor, in this regard, the bank's website should have a competitive edge when compared with other banks' online interfaces. This should be realized in the website's design and content. In addition, technology innovative, state of the

Table IV.

The results of the seventh hypothesis test by using one-way ANOVA

\begin{tabular}{lcccc}
\hline The variable & Calculated $F$ & Tabulated $F$ & Sig. & Hypothesis \\
\hline Age & 17.408 & 1.97 & 0.000 & Supported \\
Employment category & 3.281 & 1.97 & 0.012 & Supported \\
Education level & 3.319 & 1.97 & 0.011 & Supported \\
Monthly salary & 4.873 & 1.97 & 0.001 & Supported \\
\hline
\end{tabular}


art and diverse services should always be first introduced to customers before other competing banks. E-trust was ranked the second priority which emphasizes the need for developing reliable website supported with high technical expertise and consistent information representing ethical standards and integrity compared to other banks' websites.

The third priority is related to e-loyalty. Banks should promote an enjoyable and more rewarding experience (compared to competitors) in using their online banking services. This will be a catalyst in ensuring loyal customers. The results of this study reveal that loyal customers will continue dealing with the bank in the future, would recommend the bank to others and will have trust in the bank.

As a fourth priority, Palestinian banks should give high attention to personalize the usage experience of their customers in designing and delivering online services. This requires making life easier for customers to use the bank's website regardless of the customer's device (computer, smart phone, etc.). The fifth priority requires Palestinian banks to assure customers about how their personally identifiable information will be used. In this regard, banks should point out how they will secure privacy and confidentiality when it comes to customers' information, which should be dealt with anonymously. This is crucial as customers pointed out that they are sensitive about giving out information regarding their preferences. The last priority is related to the technology adoption propensity. The mean value for this factor was the lowest. This can be due to various factors specific to the Palestinian context, including lack of electricity and internet services, and restrictions on movement.

\section{Theoretical implication}

The aim of this research has been to identify the factors that affect customer adoption of online banking in Palestine, which can be useful to researchers in general and online banking managers in particular. This study is one of the few empirical studies to have investigated the adoption of online banking in the Arab world and the first in Palestine, which is considered one unique country in the world seeking independence and state building.

Most of the prior research investigated the behavioral intentions to use internet banking, such as the research of Tahrinin, Al Khasawneh (2015) and Mouakket (2009) in the Arab world and Zhang et al. (2018), Arora and Sandhu (2018) and Abdinoor and Mbamba (2017) in other parts of the world, using the various models (such as TAM, UTAUT, etc.) to identify the factors affecting the intentions to use the internet banking services. This study, however, targeted customers who use the internet banking services to identify and validate in priority order the factors that affect the usage of the internet banking. It provides empirical investigation of customers' usage of online banking in Palestine, which has provided some insights about the use of this new service in this part of the Arab world. The results provided empirical evidence that the use of internet banking in Palestine is positively related to the propensity of technology adoption, customers' value for online personalization, customers' concern for privacy, e-trust, technology and leadership and e-loyalty. This represents a contribution to the related literature about the acceptance of a new technology highlighting the knowledge gap with respect to the factors affecting the use of online banking in Palestine.

Finally, the study validated the theoretical framework and showed the applicability of the six constructs (propensity of technology adoption, customers' value for online personalization, customers' concern for privacy, e-trust, technology and leadership and e-loyalty) in identifying the factors that can affect customers' usage of online banking in Palestine.

\section{Managerial implications}

Knowing the factors affecting online banking customers' behavior and the relationship between these factors, local and foreign bank managers in Palestine can develop their marketing strategies to ensure that people use these relatively new services. The findings

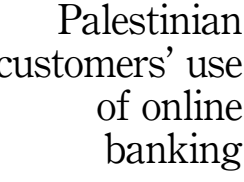


show that in order to achieve this goal, attention must be given to designing easy to use personalized and private useful systems. Advertising campaigns should be designed to create positive attitudes toward usefulness, ease of use in the customers regarding their adoption and usage of online banking service. Therefore, banks need to invest more in the most recent state of the art infrastructure of information and communication technology in addition to providing all the needed facilities for the customers such as designing advertising campaigns and establishing customer service centers to provide technical support. By doing so, customers are more likely to continue using the internet banking and ask for additional online services. In addition, banks should also make use of the customers' loyalty and trust emphasizing the positive safety features of the system during any advertising campaign. Hence, when internet banking is secure and builds an innovative reputation, bank customers' will continue to use the system which eventually will increase the number of customers using internet banking in Palestine. Therefore, practitioners should continuously improve the quality of their internet banking system based on users' feedback in order to attract more users and meet their expectations and needs to perform banking transactions at anytime and anywhere.

\section{Practical implications}

The findings of this study could help banks operating in Palestine to develop strategies that create trust and improve users' satisfaction and ultimately the continuance usage of their online banking. In this regard, several observations may be of interest to bank managers interested in improving online banking services for their banks. Bank managers need to understand that people with higher propensity to use technology are more readily prepared to use online banking services. This implies the need for banks operating in Palestine to reinforce trust and confidence among their internet banking customers. In this regard, banks should develop and maintain a robust internet banking systems that provides personalized and secured performance of their banking transactions. Banks should also develop trust building measures to ensure continuance usage of internet banking. This requires that banks continue to ensure the security of their internet banking websites. Furthermore, the banks must create internet banking websites that are easy to navigate with up-to-date and relevant information that customers need to perform their online transactions. Banks should also continue communicating the usefulness and benefits of internet banking related to time, convenience, effort and cost. Additionally, customers' concerns for privacy must also be addressed promptly, in this regard, banks should constantly remind customers that their personal and financial information is safe.

\section{Limitations and future research}

This study, like any others, has limitations. The data collection method was self-reported data. It is recommended to use the data triangulation method in any further research work to more accurately assess the factors affecting Palestinian customers in using the online banking services. In addition, the study was based on cross-sectional data collection, rather than a longitudinal study which can be adopted in a future investigation.

\section{References}

Aaker, J. (1997), "Dimensions of brand personality", Journal of Marketing Research, Vol. 34 No. 3, pp. 347-356.

Abdinoor, A. and Mbamba, U. (2017), "Factors influencing consumers' adoption of mobile financial services in Tanzania”, Cogent Business \& Management, Vol. 4 No. 1, pp. 1-19. 
Abu Shanab, E., Pearson, J. and Setterstrom, A. (2010), "Internet banking and customers' acceptance in Jordan: the unified model's perspective", Communications of the Association for Information Systems, Vol. 26 No. 23, pp. 494-524.

Ajzen, I. (1991), "The theory of planned behavior", Organizational Behavior and Human Decision Processes, Vol. 50 No. 2, pp. 179-211.

Ajzen, I. and Fishbein, M. (1980), Understanding Attitudes and Predicting Social Behaviour, Prentice-Hall, Englewood Cliffs, NJ.

Al-Ajam, A. and Nor, K. (2015), "Challenges of adoption of internet banking service in Yemen", International Journal of Bank Marketing, Vol. 33 No. 2, pp. 178-194.

Al-Gahtani, S. (2011), "Modeling the electronic transactions acceptance using an extended technology acceptance model", Applied Computing and Informatics, Vol. 9 No. 1, pp. 47-77.

Alhouti, S., Johnson, C. and Souza, G. (2016), "The complex web of values: the impact on online privacy concerns and purchase behavior", Iournal of Electronic Commerce Research, Vol. 17 No. 1, pp. 22-35.

Al-Jabri, I. and Sohail, M. (2012), "Mobile banking adoption: application of diffusion of innovation theory", Lournal of Electronic Commerce Research, Vol. 13 No. 4, pp. 379-391.

AlKailani, M. (2016), "Factors affecting the adoption of internet banking in Jordan: an extended TAM model", Journal of Marketing Development and Competitiveness, Vol. 10 No. 1, pp. 39-52.

Al Khasawneh, M. (2015), "An empirical examination of consumer adoption of mobile banking (M-banking) in Jordan”, Journal of Internet Commerce, Vol. 14 No. 3, pp. 341-362.

Al-Qeisi, K. (2009), "Analyzing the use of UTAUT model in explaining an online behaviour: internet banking adoption", unpublished $\mathrm{PhD}$ theses, Brunel University, London.

Alsamydai, M., Yousif, R. and Al Khasawneh, M. (2012), "The factors influencing consumers' satisfaction and continuity to deal with E banking services in Jordan", Global Journal of Management and Business Research, Vol. 12 No. 14, pp. 129-142.

Al-Smadi, M. (2012), "Factors affecting adoption of electronic banking: an analysis of the perspectives of banks' customers", International Journal of Business and Social Science, Vol. 3 No. 17 , pp. 294-309.

Amin, M. (2016), "Internet banking service quality and its implication on e-customer satisfaction and e-customer loyalty", International Journal of Bank Marketing, Vol. 34 No. 3, pp. 280-306.

Anderson, J. and Gerbing, D. (1988), "Structural equation modeling in practice: a review and recommended two-step approach”, Psychological Bulletin, Vol. 103 No. 3, pp. 411-423.

Anderson, R. and Srinivan, S. (2003), "E-satisfaction and e-loyalty: a contingency framework", Psychology and Marketing, Vol. 20 No. 2, pp. 123-138.

Arora, S. and Sandhu, S. (2018), "Usage based upon reasons: the case of electronic banking services in India”, International Journal of Bank Marketing, Vol. 36 No. 4, pp. 680-700.

Ashrafi, N. and Kuilboer, J. (2005), "Online privacy policies: an empirical perspective on self-regulatory practices", Journal of Electronic Commerce in Organizations, Vol. 3 No. 4, pp. 61-74.

Awad, N. and Krishnan, M. (2006), "The personalization privacy paradox: an empirical evaluation of information transparency and the willingness to be profiled online for personalization", MIS Quarterlv, Vol. 30 No. 1, pp. 13-28.

Ayyash, M. (2017), "Scrutiny of relationship between e-banking information quality dimensions and customer satisfaction”, Journal of Computer Sciences, Vol. 13 No. 4, pp. 78-90.

Azouzi, D. (2009), "The adoption of electronic banking in Tunisia: an exploratory study", Journal of Internet Banking and Commerce, Vol. 14 No. 3, pp. 1-11.

Bagozzi, R. and Philips, L. (1982), "Representing and testing organizational theories: a holistic construal", Administrative Science Quarterly, Vol. 27 No. 3, pp. 459-489.

Bandura, A. (1989), "Social cognitive theory", in Vasta, R. (Ed.), Annals of Child Development, Six Theories of Child Development, Vol. 6, JAI Press, Greenwich, CT, pp. 1-60. 
Bandyopadhyay, S. (2012), "Consumers' online privacy concerns: causes and effects”, Innovative Marketing, Vol. 8 No. 3, pp. 32-39.

Barker, L. (1989), "Survey research", in Emert, P. and Barker, L.B. (Eds), Measurement of Communication Behavior, Longman, New York, NY.

Bashir, M. and Albarbarawi, S. (2011), "Factors influencing the adoption of self service technologies (SSTs)", master thesis, Umeå University, Umea.

Boateng, J., Atuahene, A. and Boateng, J. (2015), "Leadership roles in Internet banking adoption”, International Journal of Economics, Commerce and Management, Vol. III No. 5, pp. 1609-1624.

Bultum, A. (2014), "Factors affecting adoption of electronic banking system in Ethiopian banking industry", Journal of Management Information System and E-commerce, Vol. 1 No. 1, pp. 1-17.

Chebat, J. and Cohen, A. (1993), "Response speed in mail surveys: beware of shortcuts", Marketing Research, Vol. 5 No. 2, pp. 20-25.

Chellappa, R. (2001), "The role of perceived privacy and perceived security in the development of trust in electronic commerce transactions", working paper, ebizlab, Marshall School of Business, USC, Los Angeles, CA.

Chellappa, R. and Dutta, S. (2001), "Dimensions of web-based personalization: organizing for customer asset management", working paper, ebizlab, Marshall School of Business, USC, Los Angeles, CA.

Chellappa, R. and Sin, R. (2001), "Online personalization versus privacy concerns: modeling the flip sides of the same coin”, working paper, ebizlab, Marshall School of Business, USC, Los Angeles, CA.

Chellappa, R. and Sin, R. (2005), "Personalization versus privacy: an empirical examination of the online consumer's dilemma”, Information Technology and Management, Vol. 6 Nos 2-3, pp. 181-202.

Chen, L. and Yang, T. (2014), "Increasing customer loyalty in internet marketing", Intelligent Data Analysis and its Applications, Vol. II, pp. 95-103.

Chin, W. (1998), "Issues and opinion on structural equation modeling”, MIS Quarterly, Vol. 22 No. 1, pp. 7-16.

Chiu, J., Bool, N. and Chiu, C. (2017), "Challenges and factors influencing initial trust and behavioral intention to use mobile banking services in the Philippines", Asia Pacific Journal of Innovation and Entrepreneurship, Vol. 11 No. 2, pp. 246-278.

Churchill, G. (1979), “A paradigm for developing better measures of marketing constructs”, Journal of Marketing Research, Vol. 16 No. 1, pp. 64-73.

Corstjens, M. and Lal, M. (2000), "Building store loyalty through store brands", Journal of Marketing Research, Vol. 37 No. 3, pp. 281-292.

Culnan, M. (1993), “'How did they get my name'?: an exploratory investigation of consumer attitudes toward secondary information use”, MIS Quarterly, Vol. 17 No. 3, pp. 341-364.

Dalhatu, B., Abdullah, A., Ibrahim, M. and Abideen, A. (2014), "Nigerian retail customers' adoption of online banking in an Islamic bank", Global Business and Management Research: An International Journal, Vol. 6 No. 3, pp. 237-245.

Danyali, A. (2018), "Factors influencing customers' change of behaviors from online banking to mobile banking in Tejarat Bank, Iran”, Journal of Organizational Change Management, Vol. 31 No. 6, pp. 1226-1233.

Davis, F. (1989), "Perceived usefulness, perceived ease of use, and user acceptance of information technologies", MIS Quarterly, Vol. 13 No. 3, pp. 319-340.

de Ruyter, K., Wetzels, M. and Kleijnen, M. (2001), "Customer adoption of e-service: an experimental study”, International Journal of Service Industry Management, Vol. 12 No. 2, pp. 184-207.

Deci, E. and Ryan, R. (1985), Intrinsic Motivation and Self-Determination in Human Behavior, Plenum, New York, NY. 
DeLone, W. and McLean, E. (2003), "The DeLone and Mclean model of information systems success: a ten-year update", Journal of Management Information Systems, Vol. 19 No. 4, pp. 9-30.

Devaraj, S., Fan, M. and Kohli, R. (2002), "Antecedents of B2C channel satisfaction and preference: validating e-commerce metrics”, Information Systems Research, Vol. 13 No. 3, pp. 316-333.

Dick, A. and Basu, K. (1994), "Customer loyalty: toward an integrated conceptual framework", Journal of the Academy of Marketing Science, Vol. 22 No. 2, pp. 99-113.

Dinev, T. and Hart, P. (2006), "An extended privacy calculus model for e-commerce transactions", Information Systems Research, Vol. 17 No. 1, pp. 61-80.

Donnelly, C., Rimmons, G., Armstrong, G. and Fearne, A. (2015), "Digital loyalty card 'big data' and small business marketing: formal versus informal or complementary?”, International Small Business Journal, Vol. 33 No. 4, pp. 422-442.

Dwivedi, Y., Tamilmani, K., Williams, M. and Lal, B. (2014), "Adoption of M-commerce: examining factors affecting intention and behaviour of Indian consumers", International Journal of Indian Culture and Business Management, Vol. 8 No. 3, pp. 345-360.

Estrella-Ramon, A., Sánchez-Pérez, M. and Swinnen, G. (2016), "How customers' offline experience affects the adoption of online banking”, Internet Research, Vol. 26 No. 5, pp. 1072-1092.

Faja, S. and Trimi, S. (2006), "Influence of the web vendor's interventions on privacy-related behaviors in ecommerce", Communications of AIS, Vol. 17 No. 1, pp. 593-634.

Falkenreck, C. and Wagner, R. (2013), "Do customer club memberships really enhance reputation, customer satisfaction and loyalty in B-to-B relationships?", Proceedings of the 42nd EMAC Conference, Lost in Translation: Marketing in an Interconnected World, Istanbul, June 4-7.

Falkenreck, C. and Wagner, R. (2017), "The internet of things - chance and challenge in industrial business relationships", Industrial Marketing Management, Vol. 66, pp. 181-195.

Fischer, E., Gainer, B. and Bristor, J. (1997), "The sex of the service provider: does it influence perceptions of service quality?”, Journal of Retailing, Vol. 73 No. 3, pp. 361-382.

Fishbein, M. and Ajzen, I. (1975), Belief, Attitude, Intention, and Behavior: An Introduction to Theory and Research, Addison-Wesley, Reading, MA.

Flavian, C., Guinaliu, M. and Gurrea, R. (2006), "The role played by perceived usability, satisfaction and consumer trust on website loyalty", Information \& Management, Vol. 43 No. 1, pp. 1-14.

Fornell, C. and Larcker, D. (1981), "Evaluating structural equation models with unobservable variables and measurement error", Journal of Marketing Research, Vol. 18, pp. 39-50.

FTC (1996), “Consumer information privacy hearings", Federal Trade Commission, available at: www.ftc.gov (accessed August 21, 2017).

Geisser, S. (1975), "The predictive sample reuse method with applications", Journal of the American Statistical Association, Vol. 70 No. 350, pp. 320-328.

Ghobakhloo, M., Hong, T., Sabouri, M. and Zulkifli, N. (2012), "Strategies for successful information technology adoption in small and medium-sized enterprises", Information, Vol. 3 No. 1, pp. 36-67.

Gikonyo, K. (2014), "Factors influencing the adoption of internet banking in Kenya", IOSR Journal of Business and Management, Vol. 16 No. 9, pp. 60-65.

Gilaninia, S., Fattahi, A. and Mousavian, S. (2011), "Behavioral factors tend to use the internet banking services case study: system (SABA), the Melli Bank, Iran", Ardabil. International Journal of Business Administration, Vol. 2 No. 3, pp. 173-179.

Gommans, M., Krishnan, K. and Scheffold, K. (2001), "From brand loyalty to e-loyalty: a conceptual framework", Journal of Economic and Social Research, Vol. 3 No. 1, pp. 43-58.

Goodwin, C. (1991), "Privacy: recognition of a consumer right", Journal of Public Policy and Marketing, Vol. 10 No. 1, pp. 149-166.

Goodwin, C. (1996), "Communality as a dimension of service relationships", Journal of Consumer Psychology, Vol. 5 No. 4, pp. 387-415. 
Gopalakrishnan, S., Wischnevsky, J. and Damanpour, F. (2003), "A multilevel analysis of factors influencing the adoption of internet banking", IEEE Transactions on Engineering Management, Vol. 50 No. 4, pp. 413-426.

Gremler, D. and Brown, S. (1999), "The loyalty ripple effect: appreciating the full value of customers", International Journal of Service Industry Management, Vol. 10 No. 3, pp. 271-291.

Griffin, J. (1995), Customer Loyalty: How to Get It, How to Keep It, Jossey-Bass Press, San Francisco, CA.

Grubor, A. (2009), "Global marketing decision support systems", Management Information Systems, Vol. 4 No. 1, pp. 21-27.

Hartline, M. and Ferrell, O. (1996), "The management of customer-contact service employee: an empirical investigation", Journal of Marketing, Vol. 60 No. 4, pp. 52-70.

Henseler, J., Ringle, C. and Sinkovics, R. (2009), "The use of partial least squares path modeling in international marketing", in Sinkovics, R.R. and Ghauri, P.N. (Eds), New Challenges to International Marketing, Advances in International Marketing, Vol. 20, Emerald Group Publishing, pp. 277-319.

Hernando, I. and Nieto, M. (2007), "Is the internet delivery channel changing banks' performance? The case of Spanish banks", Journal of Banking and Finance, Vol. 31 No. 4, pp. 1083-1099.

Hong-Youl, H. (2004), "Factors influencing consumer perceptions of brand trust online", Journal of Product and Brand Management, Vol. 13 No. 5, pp. 329-342.

Hsu, L. and Wang, C. (2008), "A study of e-trust in online auctions", Journal of Electronic Commerce Research, Vol. 9 No. 4, pp. 310-321.

Hu, L. and Bentler, P. (1999), "Cutoff criteria for fit indexes in covariance structure analysis: conventional criteria versus new alternatives", Structural Equation Modeling: A Multidisciplinary Journal, Vol. 6 No. 1, pp. 1-55.

Jacoby, J. (1971), "Brand loyalty: a conceptual definition", Proceedings of the American Psychological Association, Vol. 6, Washington, DC, pp. 655-656.

Jacoby, J. and Chesnut, R. (1978), Brand Loyalty Measurement and Management, Wiley, New York, NY.

Jaroslav, B. (2013), "The leadership style and the productiveness of employees in the banking sector in Slovakia”, Journal of Competitiveness, Vol. 5 No. 1, pp. 39-52.

Jarvenpaa, S., Tractinsky, N. and Vitale, M. (2000), "Consumer trust in an internet store", Information Technology and Management, Vol. 1 No. 12, pp. 45-71.

Johnston, R. (1995), "The determinants of service quality: satisfiers and dissatisfiers", International Journal of Service Industry Management, Vol. 6 No. 5, pp. 53-71.

Kaabachi, S., Mrad, S. and Petrescu, M. (2017), "Consumer initial trust toward internet-only banks in France", International Journal of Bank Marketing, Vol. 35 No. 6, pp. 903-924.

Kassim, N. and Abdullah, N. (2008), "Customer loyalty in e-commerce settings: an empirical study", Electronic Markets, Vol. 18 No. 3, pp. 275-290.

Khajouei, F. and Nayebzadeh, S. (2013), "Inertia and customer loyalty in the varying levels of the zone of tolerance and alternative attractiveness", International Journal of Academic Research in Business and Social Sciences, Vol. 3 No. 7, pp. 555-571.

Khodakarami, F. and Chan, Y. (2013), "An investigation of factors affecting marketing information systems' use", Journal of Marketing Development and Competitiveness, Vol. 7 No. 2, pp. 115-121.

Khrewesh, A. (2011), "E-banking adoption model in Palestine", master thesis, An-Najah National University, Nablus.

Koufaris, M. (2002), "Applying the technology acceptance model and flow theory to online consumer behavior", Information Systems Research, Vol. 13 No. 2, pp. 205-222.

Lotto, R. (2001), Developing Trust in the Online Customer, Gartner Group.

Loukis, E. and Kyriakou, N. (2015), "Organizational factors affecting propensity to adopt cloud computing”, 48th Hawaii International Conference on System Sciences, pp. 4230-4239. 
Luarn, P. and Lin, H. (2003), "Customer loyalty model for e-service context”, Journal of Electronic Commerce Research, Vol. 4 No. 4, pp. 156-167.

McKnight, D. and Chervany, N. (2001), "Conceptualizing trust: a typology and e-commerce customer relationships model", Proceedings of the 34th Annual Hawaii's International Conference on Systems Science, IEEE Computer Society Press, Maui, HI, January 3-6.

Magotra, I., Sharma, J. and Sharma, S. (2015), "Technology adoption propensity of the banking customers in India: an insight", International Journal of Management, Accounting and Economics, Vol. 2 No. 2, pp. 111-124.

Maitah, M. and Hodrab, R. (2015), "An empirical study of critical factors of electronic banking adoption for banking sector in Palestine", Modern Applied Science, Vol. 9 No. 9, pp. 78-91.

Mansour, K. (2016), “An analysis of business' acceptance of internet banking: an integration of e-trust to the TAM”, Journal of Business \& Industrial Marketing, Vol. 31 No. 8, pp. 982-994.

Mansumitrchai, S. and Al-Malkawi, H. (2011), "Factors underlying the adoption of online banking by Mexican consumers", International Journal of Business and Management, Vol. 6 No. 9, pp. 155-169.

Mayer, R., Davis, J. and Schoormann, F. (1995), “An integrative model of organizational trust”, Academy of Management Review, Vol. 20 No. 3, pp. 709-734.

Meinert, D., Peterson, D., Criswell, J. and Crossland, M. (2006), "Privacy policy statements and consumer willingness to provide personal information", Journal of Electronic Commerce in Organizations, Vol. 4 No. 1, pp. 1-17.

Metzger, M. (2006), "Effects of site, vendor, and consumer characteristics on web site trust and disclosure", Communication Research, Vol. 33 No. 3, pp. 155-179.

Milne, G. and Gordon, M. (1993), "Direct mail privacy-efficiency trade-offs within an implied social contract framework", Journal of Public Policy \& Marketing, Vol. 12 No. 3, pp. 206-215.

Mithas, S., Ramasubbu, N., Krishnan, M. and Fornell, C. (2006), "Designing web sites for customer loyalty across business domains: a multilevel analysis", Journal of Management Information Systems, Vol. 23 No. 3, pp. 97-127.

Mittal, V. and Kamakura, W. (2001), "Satisfaction, repurchases intent, and repurchase behaviour: investigating the moderating effect of customer characteristics", Journal of Marketing Research, Vol. 38 No. 1, pp. 131-143.

Mohammadi, H. (2015), “A study of mobile banking usage in Iran”, International Journal of Bank Marketing, Vol. 33 No. 6, pp. 733-759.

Moores, T. (2005), "Do consumers understand the role of privacy seals in e-commerce?", Communications of the ACM, Vol. 48 No. 3, pp. 86-91.

Moorman, C., Deshpande, R. and Zaltman, G. (1993), "Factors affecting trust in marketing relationships", Journal of Marketing, Vol. 57 No. 1, pp. 81-101.

Morgan, R. and Hunt, S. (1994), "The commitment-trust theory of relationship marketing”, Journal of Marketing, Vol. 58 No. 3, pp. 20-38.

Mouakket, S. (2009), "Investigating the factors influencing customers' adoption of online banking in the United Arab Emirates", Journal of International Technology and Information Management, Vol. 18 No. 3, pp. 361-384.

Nader, M. and Rahim, N. (2015), "The relationship between marketing information system, brand character and customers' loyalty of sporting goods in Tabriz", Indian Journal of Fundamental and Applied Life Sciences, Vol. 5 No. S2, pp. 169-173.

Nam, C., Song, C., Park, F. and Park, E. (2006), "Consumers' privacy concerns and willingness to provide marketing-related personal information online", in Pechmann, C. and Price, L. (Eds), $N A$ - Advances in Consumer Research, Vol. 33, Association for Consumer Research, Duluth, MN, pp. 212-217.

Nanjundeswaraswamy, T. and Swamy, D. (2014), "Leadership styles”, Advances In Management, Vol. 7 No. 2, pp. 57-62. 
Nasri, W. and Charfeddine, L. (2012), "Factors affecting the adoption of internet banking in Tunisia: an integration theory of acceptance model and theory of planned behavior", Journal of High Technology Management Research, Vol. 23 No. 1, pp. 1-14.

Nunnally, J. and Bernstein, I. (1994), Psychometric Theory, 3rd ed., McGraw-Hill, New York, NY.

Oliver, R. (1999), "Whence customer loyalty”, Journal of Marketing, Vol. 63, Special Issue, pp. 33-44.

Påhlman, K. (2013), "Personalized marketing: a qualitative study on tailored marketing online from a consumer's perspective", master thesis, Lund University, Lund.

Palmer, J. (2002), "Website usability, design, and performance metrics”, Information Systems Research, Vol. 13 No. 2, pp. 151-167.

Pan, Y. and Zinkhan, G. (2006), "Exploring the impact of online privacy disclosures on consumer trust", Journal of Retailing, Vol. 82 No. 4, pp. 331-338.

Peter, A. (2015), "Factors affecting the adoption of internet banking in Nigeria", master thesis, Eastern Mediterranean University, Famagusta.

PMA (2017), “Annual report: 2016”, Palestine Monetary Authority, Ramallah, September, available at: www.pma.ps/Portals/1/Users/002/02/2/Publications/English/Annual\%20Reports/PMA \% 20 Annual\%20Reports/Annual_Report_2016.pdf

Polatoglu, V. and Ekin, S. (2001), "An empirical investigation of the Turkish consumers' acceptance of internet banking services", International Journal of Bank Marketing, Vol. 19 No. 4, pp. 156-165.

Pollach, I. (2005), "A typology of communicative strategies in online privacy policies: ethics, power and informed consent”, Journal of Business Ethics, Vol. 62 No. 3, pp. 221-235.

Pollach, I. (2006), "Privacy statements as a means of uncertainty reduction in WWW interactions", Journal of Organizational \& End User Computing, Vol. 18 No. 1, pp. 23-49.

Potgieter, M., De Jager, J. and Heerden, A. (2010), "Marketing information system innovation for South African tour operators", Journal of Digital Marketing, Vol. 1 No. 2, pp. 89-105.

Qin, L., Kim, Y., Hsu, J. and Tan, X. (2011), "The effects of social influence on user acceptance of online social networks", International Journal of Human-Computer Interaction, Vol. 27 No. 9, pp. 885-899.

Qureshi, T., Zafar, M. and Khan, M. (2008), "Customer acceptance of online banking developing economies", Journal of Internet Banking and Commerce, Vol. 13 No. 1, pp. 1-9.

Ratchford, M. and Barnhart, M. (2012), "Development and validation of the technology adoption propensity (TAP) index", Journal of Business Research, Vol. 65 No. 8, pp. 1209-1215.

Reichheld, F. (1993), “Loyalty-based management”, Harvard Business Review, Vol. 71 No. 2, pp. 64-73.

Reichheld, F. and Sasser, W. (1990), "Zero defections: quality comes from services”, Harvard Business Review, Vol. 68, pp. 105-111.

Reichheld, F. and Schefter, P. (2000), "E-loyalty: your secret weapon on the web", Harvard Business Review, Vol. 78 No. 4, pp. 105-113.

Ringle, C., Wende, S. and Becker, J. (2015), SmartPLS 3, SmartPLS GmbH, Boenningstedt.

Salegna, G. (2018), "Classification model and e-loyalty implications for online services", International Journal of Quality and Service Sciences, Vol. 10 No. 1, pp. 72-83.

Saunders, M., Lewis, P. and Thornhill, A. (2012), Research Methods for Business Students, 6th ed., Pearson Education Limited, London.

Schultz, D. (2000), "Customer brand loyalty in an interactive marketplace", Journal of Advertising, Vol. 40 No. 3, pp. 41-53.

Schuster, O., Falkenreck, C. and Wagner, R. (2016), "The acceptance of mobile payments in the German retail market", Proceedings of STRATEGICA 2016 - Opportunities and Risks in the Contemporary Business, Tritonic, Bucharest, pp. 283-295.

Shankar, V., Urban, G. and Sultan, F. (2002), "Online trust: a stakeholder perspective, concepts, implications, and future directions", Journal of Strategic Information Systems, Vol. 11, pp. 325-344.

Shatat, A. (2017), "Factors affecting the adoption and usage of online services in Oman", Journal of Internet Banking and Commerce, Vol. 22 No. S7, pp. 1-24. 
Sheehan, K. and Hoy, M. (2000), "Dimensions of privacy concern among online consumers", Journal of Public Policy \& Marketing, Vol. 19 No. 1, pp. 62-72.

Shih, Y. and Fang, K. (2004), "The use of a decomposed theory of planned behaviour to study internet banking in Taiwan", Internet Research, Vol. 14 No. 3, pp. 213-223.

Siekpe, J. (2005), "An examination of the multidimensionality of the flow construct in a computermediated environment”, Journal of Electronic Commerce Research, Vol. 6 No. 1, pp. 31-43.

Sikdar, P., Kumar, A. and Makkad, M. (2015), "Online banking adoption: a factor validation and satisfaction causation study in the context of Indian banking customers", International Journal of Bank Marketing, Vol. 33 No. 6, pp. 760-785.

Smith, J., Sandra, J. and Sandrea, J. (1996), "Information privacy: measuring individuals' concerns about corporate practices”, MIS Quarterly, Vol. 20 No. 2, pp. 167-196.

Sohrabi, M., Yee, J. and Nathan, R. (2013), "Critical success factors for the adoption of e-banking in Malaysia”, International Arab Journal of e-Technology, Vol. 3 No. 2, pp. 76-82.

Sreejesh, S., Anusree, M. and Mitra, A. (2016), "Effect of information content and form on customers' attitude and transaction intention in mobile banking: Moderating role of perceived privacy concern”, International Journal of Bank Marketing, Vol. 34 No. 7, pp. 1092-1113.

Srinivasan, S., Anderson, R. and Ponnavolu, K. (2002), "Customer loyalty in e-commerce: an exploration of its antecedents", Journal of Retailing, Vol. 78, pp. 41-50.

Srivastava, S., Chandra, S. and Theng, Y. (2010), "Evaluating the role of trust in consumer adoption of mobile payment systems: an empirical analysis", Communications of the Association for Information Systems, Vol. 27 No. 29, pp. 561-588.

Stewart, K. and Segars, A. (2002), "An empirical examination of the concern for information privacy instrument", Information Systems Research, Vol. 13 No. 1, pp. 36-49.

Stone, M. (1974), "Cross-validatory choice and assessment of statistical predictions", Journal of the Royal Statistical Society: Series B (Methodological), Vol. 36 No. 2, pp. 111-147.

Tarhini, A., El-Masri, M., Ali, M. and Serrano, A. (2016), "Extending the UTAUT model to understand the customers' acceptance and use of internet banking in Lebanon: a structural equation modeling approach”, Information Technology \& People, Vol. 29 No. 4, pp. 830-849.

Taylor, S. and Baker, T. (1994), "An assessment of the relationship between service quality and customer satisfaction in the formation of consumers' purchase intentions", Journal of Retailing, Vol. 70 No. 2, pp. 163-178.

Taylor, S. and Todd, P. (1995), "Understanding information technology usage: a test of competing models", Information Systems Research, Vol. 6 No. 2, pp. 144-176.

Thakur, R. and Summey, J. (2007), "E-trust: empirical insights into influential antecedents", The Marketing Management Journal, Vol. 17 No. 2, pp. 67-80.

Thomas, R. and Maurer, V. (1997), "Database marketing practice: protecting consumer privacy", Journal of Public Policy \& Marketing, Vol. 16 No. 1, pp. 147-155.

Unyathanakorn, K. and Rompho, N. (2014), "Factors affecting customer satisfaction in online banking service", Journal of Marketing Development and Competitiveness, Vol. 8 No. 2, pp. 50-60.

Vallerand, R. (2000), "Deci and Ryan's self-determination theory: a view from the hierarchical model of intrinsic and extrinsic motivation”, Psychological Inquiry, Vol. 11 No. 4, pp. 312-318.

Van Dyke, T., Midha, V. and Nemati, H. (2007), "The effect of consumer privacy empowerment on trust and privacy concerns in e-commerce", Electronic Markets, Vol. 17 No. 1, pp. 68-81.

Venkatesh, V., Morris, M., Davis, G. and Davis, F. (2003), "User acceptance of information technology: toward a unified view”, MIS Quarterly, Vol. 27 No. 3, pp. 425-478.

Wang, M., Cho, S. and Denton, T. (2017), "The impact of personalization and compatibility with past experience on e-banking usage”, International Journal of Bank Marketing, Vol. 35 No. 1, pp. 45-55.

Williams, M., Rana, N. and Dwivedi, Y. (2015), "The unified theory of acceptance and use of technology (UTAUT): a literature review", Journal of Enterprise Information Management, Vol. 28 No. 3, pp. 443-488. 
Wittkop, A., Zulauf, K. and Wagner, R. (2018), "How digitalization changes the internationalization of entrepreneurial firms: theoretical considerations and empirical evidence", Management Dynamics in the Knowledge Economy, Vol. 6 No. 2, pp. 193-207.

Wolfinger, M. and Gilly, M. (2000), Consumers' Perceived Quality of E-Commerce Experiences, Center for Research on Information Technology and Organization. Irvine: University of California, CA.

Wu, L. (2011), “Inertia: spurious loyalty or action loyalty?", Asia Pacific Management Review, Vol. 16 No. 1, pp. 31-50.

Xu, H., Dinev, T., Smith, J. and Hart, P. (2011), "Information privacy concerns: linking individual perceptions with institutional privacy assurances", Journal of the Association for Information Systems, Vol. 12 No. 12, pp. 798-824.

Xu, X., Thong, J. and Venkatesh, V. (2014), "Effects of ICT service innovation and complementary strategies on brand equity and customer loyalty in a consumer technology market", Information Systems Research, Vol. 25 No. 4, pp. 710-729.

Yoon, S. (2002), "The antecedents and consequences of trust in online-purchase decisions", Journal of Interactive Marketing, Vol. 16 No. 2, pp. 47-63.

Yousafzai, S., Pallister, J. and Foxall, G. (2003), “A proposed model of e-trust for electronic banking”, Technovation, Vol. 23 No. 11, pp. 847-860.

Zhang, T., Lu, C. and Kizildag, M. (2018), "Banking 'on-the-go': examining consumers' adoption of mobile banking services", International Journal of Quality and Service Sciences, Vol. 10 No. 3, pp. 279-295.

\section{Further reading}

Chandra, S., Srivastava, S. and Theng, Y. (2010), "Evaluating the role of trust in consumer adoption of mobile payment systems: an empirical analysis", Communications of the Association for Information Systems, Vol. 27 No. 29, pp. 561-588.

Khater, A., Almansour, B. and Mahmoud, M. (2016), "Factors influencing customers' acceptance of internet banking services in Sudan”, International Journal of Science and Research, Vol. 5 No. 1, pp. 1429-1433.

Namahoot, K. and Laohavichien, T. (2018), "Assessing the intentions to use internet banking: the role of perceived risk and trust as mediating factors", International Iournal of Bank Marketing, Vol. 36 No. 2, pp. 256-276.

Sääksjärvi, M. and Talvinen, J. (1993), "Integration and effectiveness of marketing information systems", European Journal of Marketing, Vol. 27 No. 1, pp. 64-80.

Sánchez-Torres, J., Canada, F., Sandoval, A. and Alzate, J. (2018), "E-banking in Colombia: factors favouring its acceptance, online trust and government support", International Journal of Bank Marketing, Vol. 36 No. 1, pp. 170-183.

Schwartz, B. (1968), "The social psychology of privacy”, American Journal of Sociology, Vol. 73 No. 6 , pp. $741-752$.

Venkatesh, V. and Davis, F. (2000), "A theoretical extension of the technology acceptance model: four longitudinal field studies", Management Science, Vol. 46 No. 2, pp. 186-204.

\section{Corresponding author}

Mohammed Z. Salem can be contacted at: mrdd_salem@hotmail.com

For instructions on how to order reprints of this article, please visit our website:

www.emeraldgrouppublishing.com/licensing/reprints.htm

Or contact us for further details: permissions@emeraldinsight.com 